\title{
Different Seasonal Patterns in Song System Volume in Willow Tits and Great Tits
}

\author{
Georgia K. Longmoor ${ }^{a}$ b C. Henrik Lange ${ }^{a}$ Hannah Darvell ${ }^{a}$ Lauren Walker $^{a}$ \\ Seppo Rytkönen ${ }^{c}$ Emma Vatka ${ }^{c}$ Esa Hohtolad Markku Orellc \\ Tom V. Smulders ${ }^{a}$ \\ ${ }^{a}$ Centre for Behaviour and Evolution, Institute of Neuroscience, Newcastle University, Newcastle upon Tyne, \\ and ${ }^{b}$ The Roslin Institute, University of Edinburgh, Midlothian, UK; Departments of ${ }^{\mathrm{C} E c o l o g y}$ and ${ }^{\mathrm{d}}$ Genetics and \\ Physiology, Oulu University, Oulu, Finland
}

\section{Key Words}

HVC · Area X · Song control system · Seasonal changes ·

Paridae · Parus major P Poecile montanus

\begin{abstract}
In most species of seasonally breeding songbirds studied to date, the brain areas that control singing (i.e. the song control system, SCS) are larger during the breeding season than at other times of the year. In the family of titmice and chickadees (Paridae), one species, the blue tit (Cyanistes caeruleus), shows the typical pattern of seasonal changes, while another species, the black-capped chickadee (Poecile atricapillus), shows, at best, very reduced seasonal changes in the SCS. To test whether this pattern holds up in the two Parid lineages to which these two species belong, and to rule out that the differences in seasonal patterns observed were due to differences in geography or laboratory, we compared the seasonal patterns in two song system nuclei volumes (HVC and Area $\mathrm{X}$ ) in willow tits (Poecile montanus), closely related to blackcapped chickadees, and in great tits (Parus major), more closely related to blue tits, from the same area around Oulu,
\end{abstract}

Finland. Both species had larger gonads in spring than during the rest of the year. Great tit males had a larger HVC in spring than at other times of the year, but their Area $\mathrm{X}$ did not change in size. Willow tits showed no seasonal change in HVC or Area X size, despite having much larger gonads in spring than the great tits. Our findings suggest that the song system of willow tits and their relatives may be involved in learning and producing nonsong social vocalizations. Since these vocalizations are used year-round, there may be a year-round demand on the song system. The great tit and blue tit HVC may change seasonally because the demand is only placed on the song system during the breeding season, since they only produce learned vocalizations during this time. We suggest that changes were not observed in Area $X$ because its main role is in song learning, and there is evidence that great tits do not learn new songs after their first year of life. Further study is required to determine whether our hypothesis about the role of the song system in the learned, nonsong vocalizations of the willow tit and chickadee is correct, and to test our hypothesis about the role of Area $X$ in the great tit song system.

(c) 2016 S. Karger AG, Basel

\section{KARGER}

E-Mail karger@karger.com

www.karger.com/bbe
(C) 2016 S. Karger AG, Basel

0006-8977/16/0874-0265\$39.50/0
Tom V. Smulders

Centre for Behaviour and Evolution, Institute of Neuroscience

Newcastle University, Framlington Place

Newcastle upon Tyne, NE2 4HH (UK)

E-Mail tom.smulders@ncl.ac.uk 


\section{Introduction}

The song control system (SCS) of many seasonally breeding songbirds undergoes seasonal plasticity in size, as well as changes in many other aspects of anatomy and physiology [De Groof et al., 2008; Meitzen and Thompson, 2008; Meitzen et al., 2009; Ball and Balthazart, 2010]. In the rufous-collared sparrow (Zonotrichia capensis), a tropical songbird, the song system is also larger when in breeding condition [Moore et al., 2004]. Typically, the brain areas of the SCS, especially the nucleus HVC (used as a proper name, not an abbreviation), are larger at the time of year when birds sing the most, and these effects have been found both in the lab and in the field. However, in a few species of seasonal breeders, plasticity in the SCS has been either difficult to demonstrate or is reduced in the field, e.g. wild canaries (Serinus canaria) [Leitner et al., 2001] and black-capped chickadees (Poecile atricapillus) [Phillmore et al., 2006, 2015; Smulders et al., 2006].

The black-capped chickadee follows the typical seasonal songbird pattern in which males sing a courtship/ territorial song in the spring breeding season, at the same time as the gonads regrow and testosterone levels increase [Smulders et al., 2006; Avey et al., 2008]. Nevertheless, in wild-caught specimens of this species, seasonal changes in the SCS have been difficult to detect [Smulders et al., 2006], except when grouping the animals by breeding condition (using testes size) rather than by season and, even then, the effect was very small. In one study, the effect was restricted to the robust nucleus of the arcopallium (RA) [Phillmore et al., 2006], but was not evident in HVC or Area X. In another study, a breeding condition effect was found on HVC but not on Area X (RA was not measured in this study); in this case, the effect size was smaller than what has been observed in other songbird species [Phillmore et al., 2015] and the sample birds had been kept in captivity for a period of time. This could be problematic, since we know that captivity can have significant effects on another part of the songbird brain, the hippocampus [Smulders et al., 2000, LaDage et al., 2009; Tarr et al., 2009; see also Calisi and Bentley, 2009, for a review of the importance of differences between captive and wild animals]. Photoperiod manipulations with black-capped chickadees in captivity do result in measurable changes in HVC, RA and Area X [MacDougall-Shackleton et al., 2003; Phillmore et al., 2005]. The seeming lack of detectable seasonal changes in the SCS of wild black-capped chickadees contrasts with the easily detectable changes (almost 60\%) in HVC and RA in blue tits (Cyanistes caeruleus), a relatively closely related species [Caro et al., 2005] (Area X was not measured in this study).

There are a number of possible explanations for why some studies fail to find seasonal changes in the SCS but others do. It could, of course, be coincidence, but repeated replication of either a failure to find changes or of at least very small changes compared to other species makes this unlikely. It is also possible that the environment in which the studies were performed matters. The results cited above on black-capped chickadees came from populations in southern Ontario [Phillmore et al., 2006] and Nova Scotia in Canada [Phillmore et al., 2015] and from central New York State, USA [Smulders et al., 2006], while the results on blue tits came from the French island of Corsica in the Mediterranean Sea [Caro et al., 2005]. It is therefore possible that the species differences in seasonal HVC plasticity reflect the very different environments in which these studies were conducted.

Alternatively, failure to detect seasonal changes may be because there are none (or very small ones) in these species. This could be due to an unknown event in the past that has removed the plasticity for changing seasonally in particular phylogenetic groups. However, this is unlikely, since both canaries (at least domesticated ones [Nottebohm, 1981; Nottebohm et al., 1986]) and black-capped chickadees still show seasonal changes when tested in captivity [MacDougall-Shackleton et al., 2003]. This suggests that the potential for seasonal changes is indeed present in these species. So why do we not see seasonal changes in the field? Even though wild canaries change their repertoire across seasons, they do not change their singing intensity and sing (and therefore use their SCS) year-round [Leitner et al., 2001]. If the year-round use of the SCS is associated with a lack of seasonal changes in SCS volumes, then one potential explanation for the Parid situation is that the species differences could reflect the different vocalization repertoires and seasonal use of these repertoires in the two species. Chickadees have a complex set of learned calls, used year-round by both sexes, and a relatively simple breeding song [Avey et al., 2008] whereas blue tits have a more complex song and lack the complex social calls of chickadees [Bijnens and Dhondt, 1984]. This would suggest that chickadees and their relatives use the SCS year-round but that blue tits and their relatives do not.

This study aims to eliminate the possibility that different environments cause differences in seasonal patterns, and verify that the different patterns observed in chickadees and blue tits are not species-specific but generalize to 
Table 1. Total sample sizes from 2006/2007 and 2015 of great tit and willow tit brains collected in the breeding season or during the rest of the year

\begin{tabular}{|c|c|c|c|c|c|c|c|}
\hline \multirow[t]{3}{*}{ Species } & \multicolumn{6}{|c|}{ Number of samples collected } & \multirow[t]{3}{*}{ Total } \\
\hline & \multicolumn{2}{|c|}{ breeding season } & \multicolumn{4}{|c|}{ rest of the year } & \\
\hline & March & April & Aug & Sept & Nov & Dec & \\
\hline Great tit & 3 & 6 & 4 & 3 & 2 & - & 18 \\
\hline Willow tit & - & 10 & 3 & 4 & 1 & 1 & 19 \\
\hline Total & \multicolumn{2}{|c|}{19} & \multicolumn{4}{|c|}{18} & 37 \\
\hline
\end{tabular}

other species in their clades. We compared the seasonal plasticity of two SCS nuclei, HVC and Area X, in two species exhibiting a different seasonal pattern of vocalizations but collected from the same environment, i.e. the willow tit (Poecile montanus) and the great tit (Parus major).

Willow tits and great tits are sedentary hole-nesting passerines. In the Oulu area of northern Finland (at $65^{\circ} 3^{\prime} \mathrm{N}, 25^{\circ} 27^{\prime} \mathrm{E}$, average elevation $15 \mathrm{~m}$ ), their main singing period occurs in March and April when breeding territories are established. The laying time of genuine first clutches is May, and the annual median onset of egg-laying ranges from the 5th to the 20th of May for the willow tit and the 7th to the 30th May for the great tit [Vatka et al. 2011, 2014]. The earliest nests have been observed on the 29th and 30th of April, respectively. In both species the earliest clutches start hatching late in May and the main nestling period is in June and early July [Orell and Ojanen, 1983]. Only the females incubate, but both parents provide parental care for their young. Both species can lay repeat clutches if the first nesting fails. Parents go through postnuptial molt, willow tits in June to August and great tits in late June to October [Orell and Ojanen, 1980].

Willow tits are closely related to the black-capped chickadee. They winter at their breeding grounds in small, highly territorial and stable groups [Koivula and Orell, 1988; Ekman, 1989]. They have a set of complex social vocalizations which they use year-round, similarly to the chickadee [Ficken et al., 1978, 1985, 1987; Haftorn, 1993; Miyasato and Baker, 1999; Baker et al., 2000]. These nonsong vocalizations have been shown to be learned, at least in the chickadee [Mammen and Nowicki, 1981; Ficken and Weise, 1984; Ficken et al., 1987; Nowicki, 1989; Shackleton et al., 1992; Kroodsma et al., 1995; Hughes et al., 1998]. Their territorial song, on the other hand, is relatively simple compared to most songbird songs [Martens and Nazarenko, 1993].

Seasonal Patterns in Song System in Two Tit Species
Great tits are more closely related to blue tits, and equally lack the social vocalizations of the chickadee [Johansson et al., 2013]. They follow the typical songbird pattern of singing a complex courtship and territorial song during the breeding season [Rost, 1990]. Great tits overwinter in constantly changing nonterritorial flocks outside their breeding territories [Ekman, 1989]. If the production of song or song-like vocalizations is a potential mechanism of seasonal changes in the SCS, then we should find seasonal changes in the SCS of great tits, but not willow tits, even when both are collected from the same environment.

\section{Materials and Methods}

\section{Animals}

The subjects were adult male great tits and willow tits captured at Oulu under license from the North Osthrobothnian Regional Environmental Centre. The birds were captured during two seasons, in 2006-2007 and April 2015. Great tits were caught using funnel traps baited with food and willow tits were caught using mist nets, song playback and decoy birds. All birds were aged in the hand based on their plumage [Svensson, 1992]. Great tits were sexed using the color and pattern of their plumage and wing length, if necessary, and willow tits by the observation of song production and wing length. Sex was confirmed after the dissection of the gonads.

\section{6-2007}

In the spring breeding season, male great tits were collected between the 24th and 30th of March 2007 and willow tits were collected between the 16th and 22nd of April 2007. The average timing of the first clutches in 2007 was the 15th of May for great tits and 10th of May for willow tits. During this sampling period, our sample from the breeding season consisted of 8 birds, i.e. 3 great tits and 5 willow tits, and our sample from the rest of the year consisted of 18 birds, i.e. 9 great tits and 9 willow tits. For Area X analyses, 1 great tit and 3 willow tit samples were not included because of tissue damage.

\section{April 2015}

To increase our breeding-season sample size, more birds were collected in April 2015. Great tits were collected between the 8th 

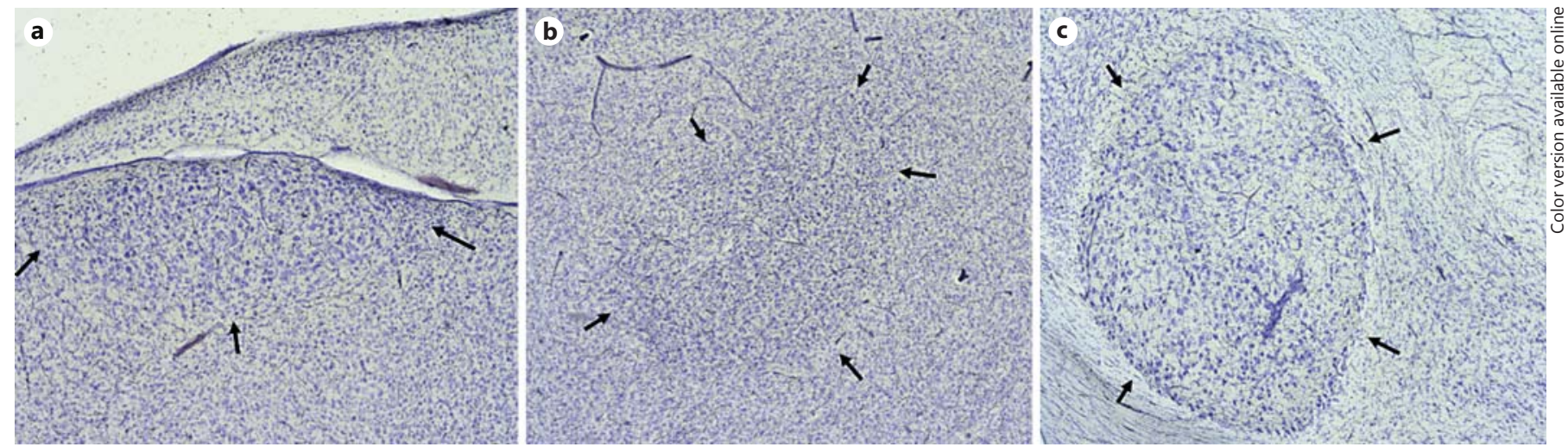

Fig. 1. Representative photomicrographs of $\operatorname{HVC}(\mathbf{a})$, Area X (b) and Rt $(\mathbf{c}) . \times 10$. Arrows indicate the borders of the nuclei.

and 16th and willow tits between the 16th and 22nd. The average timing of the first clutches in 2015 was the 14th May for great tits and 10th May for willow tits. Our sample from this period consisted of 11 birds, i.e. 6 great tits and 5 willow tits. Our exact sample sizes are indicated in table 1.

\section{Validating Breeding Condition}

To assess whether the birds were in breeding condition at the time of capture, their gonads were weighed after the birds had been humanely killed and brain dissection had been performed. In $2006 / 2007$, the gonads were rapidly frozen on dry ice after dissection. They were then shipped and weighed back in Newcastle. To quantify size, the frozen gonads were weighed in their centrifuge tubes. The weight of the same empty frozen centrifuge tube was then subtracted from all of these weights. In 2015, the gonads were weighed fresh after dissection in Finland and then discarded.

\section{Histology}

2006-2007

Birds were killed with rapid decapitation. One hemisphere of the brain was immersed in $4 \%$ formaldehyde in PBS. After $48 \mathrm{~h}$ of fixation, the hemispheres were cryoprotected in $30 \%$ sucrose solution, embedded in OCT (optimal cutting temperature compound for cryosectioning), frozen on dry ice and stored at $-80^{\circ} \mathrm{C}$. After all the samples had been collected, they were shipped from Oulu to Newcastle. They were sectioned at $70 \mu \mathrm{m}$ on a cryostat, and every other section was thaw-mounted onto gelatin-coated slides. The sections were stained with cresyl violet and cover-slipped.

\section{April 2015}

Birds were anaesthetized using isoflurane before decapitation. Both hemispheres of the brain were immersed in a solution of $4 \%$ formaldehyde in PBS. After $48 \mathrm{~h}$ of fixation, the brains were cryoprotected in $30 \%$ sucrose solution and stored at $4^{\circ} \mathrm{C}$. After all the samples had been collected, they were shipped from Oulu to Newcastle for further processing and histological measurement. They were embedded in OCT and sectioned at $40 \mu \mathrm{m}$ on a cryostat into PBS solution. Every other free-floating section was mounted onto gelatin-coated slides. The sections were then stained with cresyl violet and cover-slipped.

\section{Brain Region Morphometry}

To quantify the size of the brain areas that we were interested in, we outlined the nuclei in all sections in which they could be seen. For HVC, nucleus rotundus (Rt) and telencephalon measurements, we used Stereo Investigator ${ }^{\circledR}$ connected to a Leica DMLB microscope with a prior automated stage and an Optronics Microfire digital camera. For Area X measurements, we used Zen ${ }^{\circledR}$ connected to a Nikon Eclipse microscope with a rotatable stage and a Zeiss Axiocam 105 color camera. Figure 1 displays representative examples of the nuclei that we outlined in our morphometric analyses. Outlines were drawn using a $\times 2.5$ or $\times 2$ objective, sometimes changing to the $\times 10$ objective for the clarification of boundaries. Only half-brains were collected in 2006/2007 (equal numbers of left and right hemispheres), but we collected whole brains in 2015. For consistency, we outlined only one hemisphere in the brains collected in 2015 . We outlined equal numbers of left and right hemispheres, which were randomly allocated beforehand.

The Rt and telencephalon (both used as control areas in our analysis) were outlined by different people for the 2006-2007 samples versus the 2015 samples. All HVC and Area X outlines were performed by the same person (G.K.L.). The outlines of the $2006 / 2007$ samples were performed blinded to species and season. It was not possible to be blinded to the season of the 2015 samples since they were all collected at the same time of year; however, the outlines were performed blinded to species.

\section{6-2007 (70- $\mu \mathrm{m}$ Sections, Every Other Section Taken)}

To calculate the volume of HVC, Area X and Rt, the area of each section was multiplied by $140 \mu \mathrm{m}$ (the distance between measurements). These volumes were added up for all sections containing the nucleus of interest. To calculate the volume of the telencephalon, its surface area was measured on every 4 th section on the slides, multiplied by $560 \mu \mathrm{m}$ and then added up.

April 2015 (40- $\mu \mathrm{m}$ Sections, Every Other Section Taken)

To calculate the volume of HVC, Area X and Rt, the area of each section was multiplied by $80 \mu \mathrm{m}$. These volumes were added up for all the sections containing the nucleus of interest. To calculate the volume of the telencephalon, its surface area was measured on every 14 th section on the slides. This was then multiplied by $560 \mu \mathrm{m}$. 


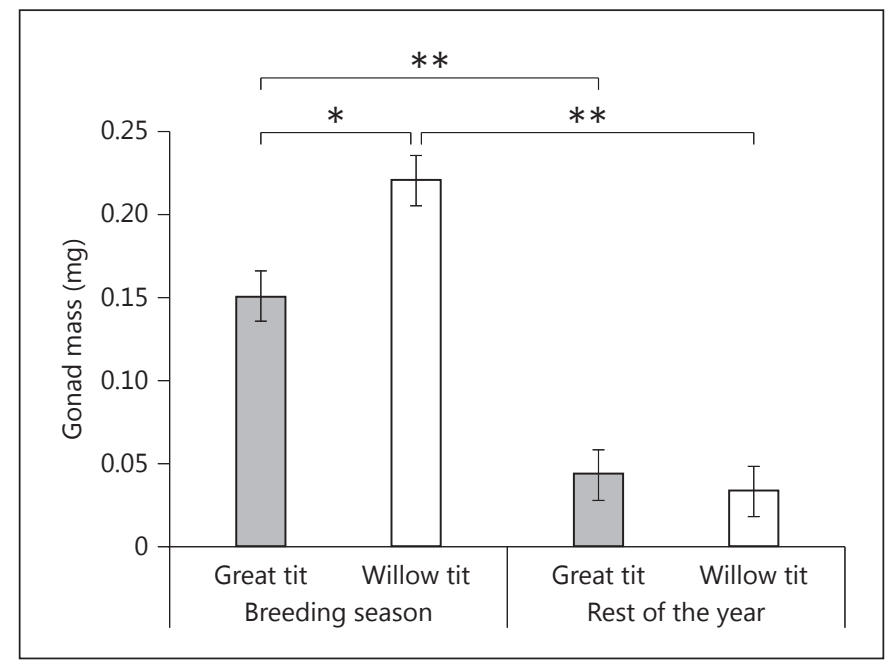

Fig. 2. Gonad mass for the two species at the different times of the year. We plotted the means for the breeding season (March to April) and the rest of the year (August to December). Error bars represent standard error. ${ }^{*} \mathrm{p}<0.05,{ }^{* *} \mathrm{p}<0.01$.

To provide a starting point and standardization of measurement, the first section where the anterior commissure was present was always one of the sections measured.

\section{Data Analysis}

We investigated differences in seasonal patterns between species by testing whether an interaction between season and species could explain variation in volumes of HVC, Area X and Rt, and in gonad weight. All measurements were natural-log-transformed for data analysis ( +1 to avoid negative scaling). The design of our statistical models are classic factorial $\mathrm{AN}(\mathrm{C}) \mathrm{OVAs}$. We implemented these in the generalized linear model function in SPSS v22 for Windows, with a linear outcome variable because this gave us a more flexible output, enabling pairwise comparisons between means. The output from these models is Wald's $\chi^{2}$. All analyses were also run as classic $\mathrm{AN}(\mathrm{C}) \mathrm{OVAs}$ and the outcomes were qualitatively the same.

Tests for HVC, Area X and Rt were run using two factors, i.e. species (willow tit/great tit) and season (breeding season/the rest of the year), and we tested for the main effects of species and season as well as for the interaction between these factors. We included the volume of the telencephalon in the model as a covariate, to control for any overall size differences between the samples because of the two different methods used to process the tissue [Smulders, 2002]. We included the telencephalon as a covariate rather than analyzing each nucleus as a percentage of the telencephalon, because ratios conflate variation in the numerator with variation in the denominator. However, we plotted our results as percentages of telencephalon to enable readers to compare them with other studies which have used these ratios in their analyses of nucleus volumes.

No other factors or interactions between factors and covariates were included in the model. Results were considered significant if $\mathrm{p}<0.05$.

\section{Results}

\section{Gonad Mass}

We measured gonad mass as a proxy of breeding condition. In both species, testes were larger in birds caught during spring (March and April) than during the rest of the year (August to December; $\chi_{1}^{2}=96.3, \mathrm{p}<0.001$ ). We also found a significant interaction between species and season $\left(\chi^{2}{ }_{1}=6.17, \mathrm{p}=0.013\right.$; fig. 2$)$. In spring, willow tits had larger testes than great tits $(\mathrm{p}=0.003)$. This effect was not present during the rest of the year when birds were not in breeding condition $(\mathrm{p}=0.593)$.

\section{Brain Morphometry}

We checked if our calculation of nucleus volumes were consistent with another measure used in the literature, the formula for a cone frustum [Smith et al., 1995]. We observed similar results and levels of significance and the two measures were significantly correlated $(\mathrm{r}=0.944, \mathrm{p}<$ 0.001 ). The analyses that we report below use our original calculation of volume.

\section{HVC Volume}

We investigated whether the volume of the SCS nucleus HVC changed seasonally in both great tits and willow tits. Telencephalon volume significantly predicted HVC volume $\left(\chi_{1}^{2}=42.84, \mathrm{p}<0.001\right)$ and there were no independent main effects of species $\left(\chi^{2}{ }_{1}=2.32, p=0.128\right)$ or season $\left(\chi_{1}^{2}=2.434, \mathrm{p}=0.119\right)$. There was, however, a significant interaction between species and season $\left(\chi^{2}{ }_{1}=\right.$ $6.56, \mathrm{p}=0.01$; fig. 3 ). In great tits, HVC volume was larger in spring than when birds were not in breeding condition $(p=0.006)$. There was no seasonal difference in HVC volume in the willow tits $(\mathrm{p}=0.652)$. Comparing the species within each breeding season, we find that breeding great tits have significantly larger HVC volumes than breeding willow tits $(\mathrm{p}=0.004)$, but this effect was not present outside of spring $(\mathrm{p}=0.498)$.

\section{Area $X$ volume}

We also investigated whether the volume of the SCS nucleus Area X changed seasonally in both great tits and willow tits. Telencephalon volume significantly predicted Area $X$ volume $\left(\chi_{1}^{2}=64.92, p<0.001\right)$ and there were no independent main effects of species $\left(\chi^{2}{ }_{1}=0.095, \mathrm{p}=\right.$ $0.758)$ or season $\left(\chi^{2}{ }_{1}=0.005, \mathrm{p}=0.944\right)$. In contrast to our analysis of HVC, we found no significant interaction between species and season $\left(\chi^{2}{ }_{1}=0.570, \mathrm{p}=0.450\right.$; fig. 3). 


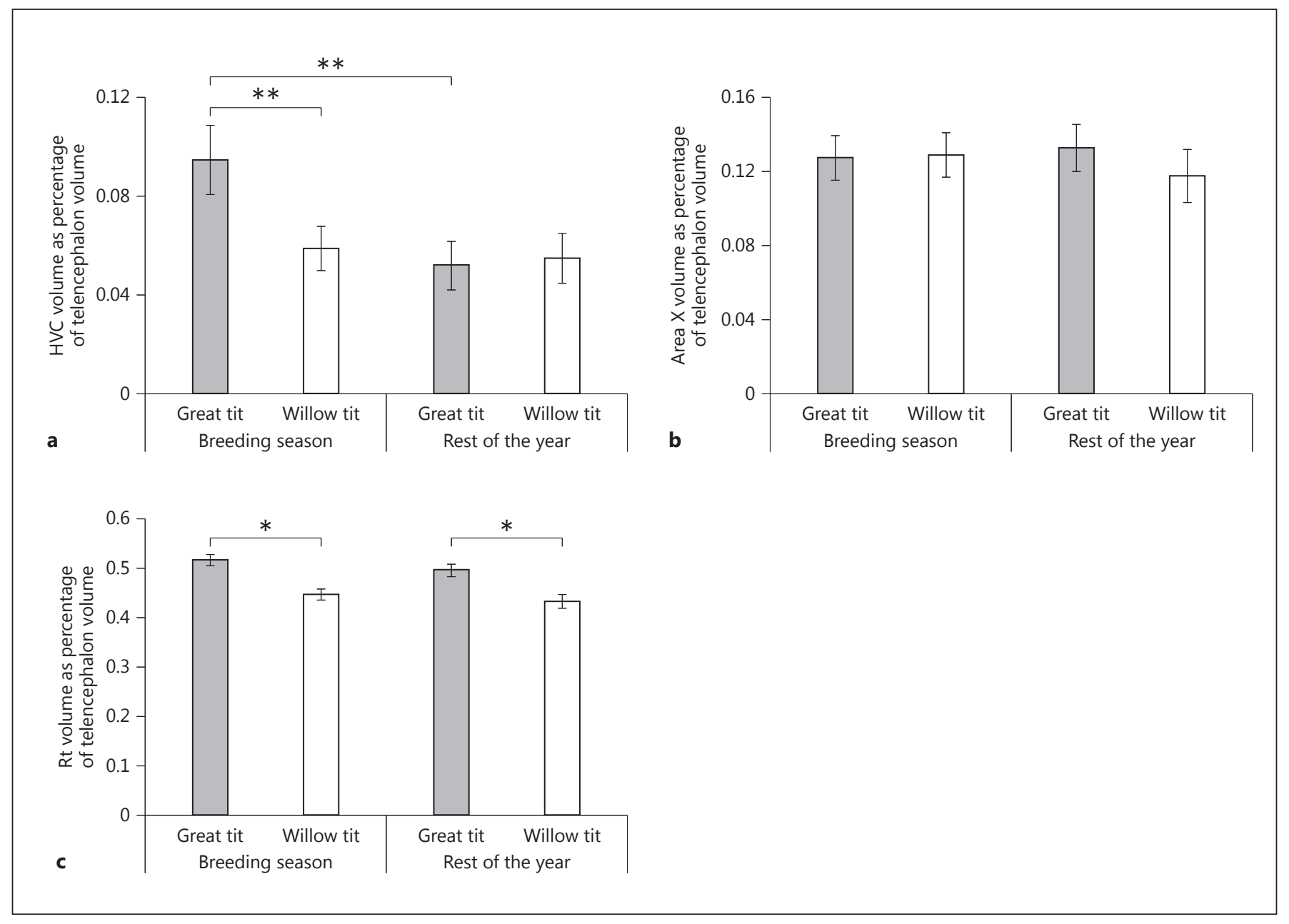

Fig. 3. Volumes for the different brain regions plotted by species and season. We plotted the means for nucleus volumes calculated as a percentage of telencephalon volume. a HVC (mean \pm SE): there is a significant seasonal difference in the great tit HVC, but not in the willow tit HVC. b Area X (mean \pm SE): there is no seasonal difference in the great tit or the willow tit Area X. c Rt (mean \pm SE): there is no seasonal difference in the great tit or the willow tit Rt, but that of the great tit is significantly larger than that of the willow tit. ${ }^{*} \mathrm{p}<0.05,{ }^{* *} \mathrm{p}<0.01$.

\section{Rt Volume}

To ensure that the seasonal effect of the increase in HVC volume was specifically in the SCS, we measured a control structure which is not involved in song control, i.e. the visual Rt [Laverghetta and Shimizu, 1999]. This is also easy to identify, making the quantification of its volume reliable and repeatable across individuals.

Telencephalon volume significantly predicted Rt volume $\left(\chi_{1}^{2}=182.73, p<0.001\right)$. As expected, we found no evidence of an effect of season on Rt volume $\left(\chi^{2}{ }_{1}=1.76\right.$, $\mathrm{p}=0.185)$ nor any interaction between species and season $\left(\chi^{2}{ }_{1}=0.17, p=0.679\right)$. However, there was a significant main effect of species; Rt was larger, relative to the telencephalon, in great tits than in willow tits $\left(\chi^{2}{ }_{1}=6.08, \mathrm{p}=\right.$ 0.014 ; fig. 3).

\section{Discussion}

\section{Main Findings}

Our results suggest seasonal stability in the size of the willow tit SCS, compared to seasonal plasticity in the size of HVC in the great tit. The lack of seasonal change in the willow tit SCS in the field is consistent with previous studies on the black-capped chickadee, a closely related 
species, for which either a reduced seasonal change or seasonal stability in the SCS have been reported [Phillmore et al., 2006, 2015; Smulders et al., 2006]. The ecology and behavior of willow tits and black-capped chickadees are very similar to each other. The finding of changes in HVC size in early spring in great tits is also consistent with previous findings on blue tits [Caro et al., 2005]. Our results give support to the hypothesis that the difference in seasonal plasticity between these two species is related to the differences in vocalizations made by the two groups of birds [Smulders et al., 2006]. These differences, in turn, relate to differences in winter social systems.

\section{Functional Explanations of Seasonal Stability}

Although we measured the size of the SCS nuclei, previous research has observed seasonal changes using alternative measures, including the number of neurons, neuronal density and the incorporation of new neurons into the nucleus [Tramontin and Brenowitz, 2000]. One explanation for our findings is that measuring volume was not sensitive enough to observe subtle seasonal changes in our sample of birds. A previous study of the blackcapped chickadee did find small seasonal changes in the SCS, which were of a smaller magnitude than the changes observed in the majority of species [Phillmore et al., 2015]. Measuring neuron numbers or neuronal density in our samples could therefore yield results different from those obtained with our measure of volume.

Nevertheless, in most songbirds, SCS volumes do change seasonally. We will first consider why HVC volume changes seasonally in great tits, but not in willow tits. Willow tits are closely related to black-capped chickadees, and have a similar large and complex repertoire of social calls which they perform year-round [Haftorn, 1993]. Great tits, in contrast, are more closely related to blue tits and, equally, lack learned social vocalizations, while possessing a complex courtship/territorial song like most other seasonally breeding songbirds studied [McGregor and Krebs, 1982]. Given these differences in call repertoire and in the seasonal pattern of vocalizations, we hypothesise that HVC is responsible for the learning and generation of the complex social call vocalizations year-round, just as it plays a role in the learned 'long call' of the zebra finch [Simpson and Vicario, 1990]. The extra singing during the breeding season then does not place sufficient demand on HVC's circuitry to lead to a large increase in volume during the breeding season. Interestingly, the size of the willow tit $\mathrm{HVC}$ is equivalent to that of the great tit nonbreeding HVC and smaller than the breeding HVC. If our hypothesis is correct, this suggests that the demands on HVC circuitry are less for learned social vocalizations and simple song than they are for the complex great tit song.

In contrast to our results for HVC, we found no evidence of seasonal plasticity in Area X in either species. The lack of seasonal plasticity in Area X volume in the willow tits is consistent with the lack of seasonal plasticity in HVC. This finding is also consistent with several other studies on seasonal songbirds which have found evidence of plasticity in one or two SCS nuclei (usually HVC) but not others. Although the study on blue tits did not measure Area X [Caro et al., 2005], two studies on the black-capped chickadee found small seasonal plasticity in HVC but not in their Area X [Phillmore et al., 2006, 2015]. $\mathrm{HVC}$ is involved in the motor production of song as well as in song learning whereas Area $\mathrm{X}$ is involved in learning, but not production. If great tits learn their song types during a critical period early in life and lose the ability to do so afterwards (close-ended song learning [Marler, 1970]), this could explain why we observed seasonal changes in the great tit HVC but not in Area X. However, there is no definite consensus about when great tits learn their song. Previous observations have suggested that great tits may learn songs from neighbors in adulthood [McGregor and Krebs, 1982; McGregor and Avery, 1986; Franco and Slabbekoorn, 2009], while a recent study suggests that these findings were due to methodological issues, and that the great tit is actually a close-ended learner [RiveraGutierrez et al., 2011].

To our knowledge, our study is the first to investigate seasonal changes in the great tit SCS. Additional studies are required to understand the lack of changes we observed in Area X and to determine when great tits learn their song. The fact that seasonal changes have been reported in HVC and RA, but not in Area X in the whitecrowned sparrow (Zonotrichia leucophrys), a confirmed close-ended learner, supports our hypothesis [Smith et al., 1995, 1997; Tramontin et al., 2000]. The growth of Area X has only been reported in this species after photoperiodic manipulations in experimental settings [Thompson and Brenowitz, 2005; Brenowitz et al., 2007]. Although we were unable to measure SCS nucleus RA because of issues concerning the quality of the tissue from the older samples, determining whether this changes seasonally in the great tit could also add strength to our hypothesis about Area X, since RA is mainly involved in motor production which does change seasonally. 
The Mechanisms of Seasonal Stability and Plasticity

The pattern that we observed in our data is consistent with the idea that HVC size is driven by the amount of vocalization performed by the birds [Sartor et al., 2005]. In great tits, the complex song is only used intensively during the breeding season. This change in usage of the motor circuit could then drive the change in HVC size. The social vocalizations in willow tits and chickadees, however, are used intensively year-round [Avey et al., 2008], resulting in seasonal stability in HVC size. The fact that breeding-condition-related changes in the SCS were detected in captive black-capped chickadees [MacDougall-Shackleton et al., 2003] supports this argument. Captive chickadees produce the same vocalizations as wild birds, but in much smaller quantities [Avey et al., 2011]. If vocal activity is indeed responsible for the size of the SCS, then the lower level of vocalizations in captivity might lead to a smaller SCS when birds are not in breeding condition (including Area X in that case; [MacDougall-Shackleton et al., 2003]). The increase in fee-bee singing observed under increasing photoperiod in the lab may then be a large enough change in the use of learned vocalizations to have a detectable effect on SCS volumes, because the baseline vocal activity is so much lower than in the field. This mechanism may also apply to other groups of songbirds, such as the European starling, where direct effects of singing activity on SCS have been reported [Ball et al., 2004; Sartor and Ball, 2005].

The fact that HVC did not change in size in the willow tit, despite their large testes and their presumably high levels of testosterone in spring suggests that, in this species, there is not a direct effect of testosterone on HVC volume as in other species [Brenowitz and Lent, 2002]. Although we did not directly measure testosterone in our population, several other studies have found seasonal changes in testosterone levels in the willow tit [Silverin, 1984, Silverin et al., 1986] and the great tit (plasma testosterone [Van Duyse et al., 2003] and testosterone-metabolizing enzymes in the brain [Silverin and Deviche, 1991]), which suggests that there could be a change in testosterone in our study species during the breeding season which matches the change in gonad size that we observed. Interestingly, for blue tits, evidence also suggests that testosterone is not an important factor in driving SCS seasonal plasticity, as SCS nuclei increase in size before the spring surge in testosterone [Caro et al., 2005]. This may mean that in Parids, in general, direct effects of testosterone on seasonal changes in SCS nucleus sizes are less likely. This is similar to red-backed fairy wrens ( Malurus melanocephalus) in which a dissociation between testosterone levels and SCS nucleus sizes has been reported [Schwabl et al., 2015], but unlike other groups of songbirds where testosterone seems to be the driving force behind seasonal plasticity in the SCS (e.g. the rufous collared sparrow [Small et al., 2015] and the canary [Madison et al., 2015]; review [Tramontin and Brenowitz, 2000]). Additional studies of seasonal changes in the Parid song system which directly measure and manipulate testosterone levels, both systemically and locally [Tramontin et al., 2000; Brenowitz et al., 2007; Meitzen et al., 2007], are necessary to determine whether our hypothesis is correct.

\section{Conclusion}

In conclusion, this study is the first to directly compare seasonal changes in SCS between two Parid species from the same environment that exhibit differences in song behavior. Our results confirm the lack of seasonal changes in HVC and Area X in the 'atypical' species which produces complex social vocalizations year-round in addition to its simple courtship song, and the existence of seasonal plasticity in the HVC of the more 'typical' species which has a much smaller, simpler repertoire of nonsong vocalizations but a more complex courtship song. We suggest that the willow tit HVC and Area X are stable in size throughout the year in the field because these nuclei are involved in the learning and production of social vocalizations as well as the courtship song. Area X may not change seasonally in great tits because they are potentially close-ended learners. Direct study of the role of HVC and Area $\mathrm{X}$ in the song and nonsong vocalizations in different Parid species will be required to test our hypotheses.

\section{Acknowledgements}

This study was funded by a grant from the Biotechnology and Biological Sciences Research Council (BBSRC), UK, reference No. BB/C006186/1 to T.V.S.; G.K.L. was funded by a Newcastle University Postgraduate Scholarship in 2015; M.O. was funded by the Academy of Finland Research Council for Biosciences and Environment (project No. 258638). 


\section{References}

Avey MT, Quince AF, Sturdy CB (2008): Seasonal and diurnal patterns of black-capped chickadee (Poecile atricapillus) vocal production. Behav Process 77:149-155.

-Avey MT, Rodriguez A, Sturdy CB (2011): Seasonal variation of vocal behaviour in a temperate songbird: assessing the effects of laboratory housing on wild-caught, seasonally breeding birds. Behav Process 88:177-183.

- Baker MC, Howard TM, Sweet PW (2000): Microgeographic variation and sharing of the gargle vocalization and its component syllables in black-capped chickadee (Aves, Paridae, Poecile atricapillus) populations. Ethology 106:819-838.

- Ball GF, Auger CJ, Bernard DJ, Charlier TD, Sartor JJ, Riters LV, Balthazart J (2004): Seasonal plasticity in the song control system: multiple brain sites of steroid hormone action and the importance of variation in song behavior. Ann NY Acad Sci 1016:586-610.

-Ball GF, Balthazart J (2010): Seasonal and hormonal modulation of neurotransmitter systems in the song control circuit. J Chem Neuroanat 39:82-95.

Bijnens L, Dhondt AA (1984): Vocalizations in a Belgian blue tit, Parus c. caeruleus, population. De Giervalk 74:243-269.

Brenowitz EA, Lent K (2002): Act locally and think globally: intracerebral testosterone implants induce seasonal-like growth of adult avian song control circuits. Proc Natl Acad Sci 99:12421-12426.

Brenowitz EA, Lent K, Rubel EW (2007): Auditory feedback and song production do not regulate seasonal growth of song control circuits in adult white-crowned sparrows. J Neurosci 27:6810-6814.

Calisi RM, Bentley GE (2009): Lab and field experiments: are they the same animal? Horm Behav 56:1-10.

-Caro SP, Lambrechts MA, Balthazart JB (2005): Early seasonal development of brain song control nuclei in male blue tits. Neurosci Lett 386:139-144.

De Groof G, Verhoye M, Van Meir V, Balthazart J, Van Der Linden A (2008): Seasonal rewiring of the songbird brain: an in vivo MRI study. Eur J Neurosci 28:2475-2485.

Ekman J (1989): Ecology of non-breeding social systems of Parus. Wilson Bull 101:263-288.

-Ficken MS, Ficken RW, Apel KM (1985): Dialects in a call associated with pair interactions in the black-capped chickadee. Auk 102:145151.

-Ficken MS, Ficken RW, Witkin SR (1978): Vocal repertoire of the black-capped chickadee. Auk 95:34-48.

Ficken MS, Weise CM (1984): A complex call of the black-capped chickadee (Parus atricapillus). I. Microgeographic variation. Auk 101: 349-360.
Ficken MS, Weise CM, Reinartz JA (1987): A complex vocalization of the black-capped chickadee. II. Repertoires, dominance and dialects. Condor 89:500-509.

Franco P, Slabbekoorn H (2009): Repertoire size and composition in great tits: a flexibility test using playbacks. Anim Behav 77:261-269.

Haftorn S (1993): Ontogeny of the vocal repertoire in the willow tit Parus montanus. Ornis Scand 24:267-289.

Hughes M, Nowicki S, Lohr B (1998): Call learning in black-capped chickadees (Parus atricapillus): the role of experience in the development of 'chick-a-dee' calls. Ethology 104:232249.

Johansson US, Ekman J, Bowie RC, Halvarsson P, Ohlson JI, Price TD, Ericson PG (2013): A complete multilocus species phylogeny of the tits and chickadees (Aves: Paridae). Mol Phylogenet Evol 69:852-860.

Koivula K, Orell M (1988): Social rank and winter survival in the willow tit Parus montanus. Ornis Fennica 65:114-120.

Kroodsma DE, Albano DJ, Houlihan PW, Wells JA (1995): Song development by blackcapped chickadees (Parus atricapillus) and Carolina chickadees (P. carolinensis). Auk 112:29-43.

LaDage LD, Roth TC II, Fox RA, Pravosudov VV (2009): Effects of captivity and memorybased experiences on the hippocampus in mountain chickadees. Behav Neurosci 123: 284.

Laverghetta AV, Shimizu T (1999). Visual discrimination in the pigeon (Columba livia): effects of selective lesions of the nucleus rotundus. Neuroreport 10:981-985.

Leitner S, Voigt C, Gahr M (2001): Seasonal changes in the song pattern of the non-domesticated island canary (Serinus canaria) a field study. Behaviour 138:885-904.

Leitner S, Voigt C, Garcia-Segura LM, Van't Hof T, Gahr M (2001): Seasonal activation and inactivation of song motor memories in wild canaries is not reflected in neuroanatomical changes of forebrain song areas. Horm Behav 40:160-168.

MacDougall-Shackleton SA, Hernandez AM, Valyear KF, Clark AP (2003): Photostimulation induces rapid growth of song-control brain regions in male and female chickadees (Poecile atricapilla). Neurosci Lett 340:165168.

Madison FN, Rouse ML, Balthazart J, Ball GF (2015): Reversing song behavior phenotype: testosterone driven induction of singing and measures of song quality in adult male and female canaries (Serinus canaria). Gen Comp Endocrinol 215:61-75.

Mammen DL, Nowicki S (1981): Individual differences and within-flock convergence in chickadee calls. Behav Ecol Sociobiol 9:179_ 186.
Marler P (1970): A comparative approach to vocal learning: song development in white-crowned sparrows. J Comp Physiol Psychol 71(2p2):1.

Martens J, Nazarenko AA (1993): Microevolution of eastern palaearctic grey tits as indicated by their vocalizations [Parus (Poecile) Paridae, Aves]. I. Parus montanus: contributions to the fauna of the far east, No. 2. J Zool System Evol Res 31:127-143.

McGregor PK, Avery MI (1986): The unsung songs of great tits (Parus major): learning neighbours' songs for discrimination. Behav Ecol Sociobiol 18:311-316.

McGregor PK, Krebs JR (1982): Song types in a population of great tits (Parus major): their distribution, abundance and acquisition by individuals. Behaviour 79:126-152.

Meitzen J, Moore IT, Lent K, Brenowitz EA, Perkel DJ (2007): Steroid hormones act transsynaptically within the forebrain to regulate neuronal phenotype and song stereotypy. J Neurosci 27:12045-12057.

Meitzen J, Thompson CK (2008): Seasonal-like growth and regression of the avian song control system: neural and behavioral plasticity in adult male Gambel's white-crowned sparrows. Gen Comp Endocrinol 157:259-265.

Meitzen J, Weaver AL, Brenowitz EA, Perkel DJ (2009): Plastic and stable electrophysiological properties of adult avian forebrain song-control neurons across changing breeding conditions. J Neurosci 29:6558-6567.

Miyasato LE, Baker MC (1999): Black-capped chickadee call dialects along a continuous habitat corridor. Anim Behav 57:1311-1318.

-Moore IT, Wingfield JC, Brenowitz EA (2004): Plasticity of the avian song control system in response to localized environmental cues in an equatorial songbird. J Neurosci 24:1018210185.

Nottebohm F (1981): A brain for all seasons: cyclical anatomical changes in song control nuclei of the canary brain. Science 214:13681370.

Nottebohm F, Nottebohm ME, Crane L (1986): Developmental and seasonal changes in canary song and their relation to changes in the anatomy of song-control nuclei. Behav Neural Biol 46:445-471.

Nowicki S (1989): Vocal plasticity in captive black-capped chickadees: the acoustic basis and rate of call convergence. Anim Behav 37: 64-73.

Orell M, Ojanen M (1980): Overlap between breeding and moulting in the great tit Parus major and the willow tit $P$. montanus in northern Finland. Ornis Scand 11:43-49.

Orell M, Ojanen M (1983): Timing and length of the breeding season of the great tit (Parus major) and the willow tit (P. montanus) near Oulu, northern Finland. Ardea 71:183-198. 
-Phillmore LS, Hoshooley JS, Hahn TP, MacDougall-Shackleton SA (2005): A test of absolute photorefractoriness and photo-induced neural plasticity of song-control regions in blackcapped chickadees (Poecile atricapillus). Can J Zool 83:747-753.

- Phillmore LS, Hoshooley JS, Sherry DF, MacDougall-Shackleton SA (2006): Annual cycle of the black-capped chickadee: seasonality of singing rates and vocal-control brain regions. J Neurobiol 66:1002-1010.

-Phillmore LS, MacGillivray HL, Wilson KR, Martin S (2015): Effects of sex and seasonality on the song control system and Foxp2 protein expression in black-capped chickadees (Poecile atricapillus). Dev Neurobiol 75:203-216.

-Rivera-Gutierrez HF, Pinxten R, Eens M (2011): Difficulties when assessing birdsong learning programmes under field conditions: a reevaluation of song repertoire flexibility in the great tit. PLoS One 6:e16003.

Rost R (1990): Hormones and behaviour. A joint examination of studies on seasonal variation in song production and plasma levels of testosterone in the great tit Parus major. J Ornithol 131:403-412.

-Sartor JJ, Ball GF (2005): Social suppression of song is associated with a reduction in volume of a song-control nucleus in European starlings (Sturnus vulgaris). Behav Neurosci 119: 233.

-Sartor JJ, Balthazart J, Ball GF (2005): Coordinated and dissociated effects of testosterone on singing behavior and song control nuclei in canaries (Serinus canaria). Horm Behav 47: 467-476.

-Schwabl H, Dowling J, Baldassarre DT, Gahr M, Lindsay WR, Webster MS (2015): Variation in song system anatomy and androgen levels does not correspond to song characteristics in a tropical songbird. Anim Behav 104:39-50.
-Shackleton SA, Ratcliffe L, Weary DM (1992): Relative frequency parameters and song recognition in black-capped chickadees. Condor 94:782-785.

-Silverin B (1984): Annual gonadotropin and testosterone cycles in free-living male birds. J Exp Zool 232:581-587.

Silverin B, Deviche P (1991): Biochemical characterization and seasonal changes in the concentration of testosterone-metabolizing enzymes in the European great tit (Parus major) brain. Gen Comp Endocrinol 81:146-159.

- Silverin B, Viebke PA, Westin J (1986): Seasonal changes in plasma levels of $\mathrm{LH}$ and gonadal steroids in free-living willow tits Parus montanus. Ornis Scand 230-236.

- Simpson HB, Vicario DS (1990): Brain pathways for learned and unlearned vocalizations differ in zebra finches. J Neurosci 10:1541-1556.

Small TW, Brenowitz EA, Wojtenek W, Moore IT (2015): Testosterone mediates seasonal growth of the song control nuclei in a tropical bird. Brain Behav Evol 86:110-121.

-Smith GT, Brenowitz EA, Beecher MD, Wingfield JC (1997): Seasonal changes in testosterone, neural attributes of song control nuclei, and song structure in wild songbirds. J Neurosci 17:6001-6010.

Smith GT, Brenowitz EA, Wingfield JC, Baptista LF (1995): Seasonal changes in song nuclei and song behavior in Gambel's whitecrowned sparrows. J Neurobiol 28:114-125.

Smulders TV (2002): Natural breeding conditions and artificial increases in testosterone have opposite effects on the brains of adult male songbirds: a meta-analysis. Horm Behav 41: 156-169.
Smulders TV, Casto JM, Nolan V, Ketterson ED, DeVoogd TJ (2000): Effects of captivity and testosterone on the volumes of four brain regions in the dark-eyed junco (Junco hyemalis). J Neurobiol 43:244-253.

-Smulders TV, Lisi MD, Tricomi E, Otter KA, Chruszcz B, Ratcliffe LM, DeVoogd TJ (2006): Failure to detect seasonal changes in the song system nuclei of the black-capped chickadee (Poecile atricapillus). J Neurobiol 66:991-1001.

Svensson L (1992): Identification Guide to European Passerines. British Trust for Ornithology.

Tarr BA, Rabinowitz JS, Imtiaz MA, DeVoogd TJ (2009): Captivity reduces hippocampal volume but not survival of new cells in a foodstoring bird. Dev Neurobiol 69:972-981.

Thompson CK, Brenowitz EA (2005): Seasonal change in neuron size and spacing but not neuronal recruitment in a basal ganglia nucleus in the avian song control system. J Comp Neurol 481:276-283.

-Tramontin AD, Brenowitz EA (2000): Seasonal plasticity in the adult brain. Trends Neurosci 23:251-258.

- Tramontin AD, Hartman VN, Brenowitz EA (2000): Breeding conditions induce rapid and sequential growth in adult avian song control circuits: a model of seasonal plasticity in the brain. J Neurosci 20:854-861.

-Van Duyse E, Pinxten R, Eens M (2003): Seasonal fluctuations in plasma testosterone levels and diurnal song activity in free-living male great tits. Gen Comp Endocrinol 134:1-9.

-Vatka E, Orell M, Rytkönen S (2011): Warming climate advances breeding and improves synchrony of food demand and food availability in a boreal passerine. Glob Change Biol 17: 3002-3009.

-Vatka E, Rytkönen S, Orell M (2014): Does the temporal mismatch hypothesis match in boreal populations? Oecologia 176:595-605. 


\section{Erratum}

In the discussion of our recent paper [Longmoor et al., 2016], we mistakenly stated that seasonal changes in Area X had not been detected in wild-caught white-crowned sparrows (Zonotrichia leucophrys). In fact, the species in which one field study did not detect seasonal changes in Area X was the song sparrow (Melospiza melodia [Smith et al., 1997]). We cited this observation as potential support for our speculation that the lack of seasonal changes in Area $\mathrm{X}$ in great tits (Parus major) might be related to this species also being a closed-ended learner. We should have also noted, however, that seasonal changes in Area X have been described in this same species in another field study [Thompson and Brenowitz, 2005] and in other closed-ended learners (e.g. table 2 in Tramontin and Brenowitz [2000]). This makes our speculative explanation of the lack of seasonal changes in Area $\mathrm{X}$ in great tits less likely, and leaves us to wonder why this might be the case. We apologize for the inaccuracies in our initial discussion.

Longmoor GK, Lange CH, Darvell H, Walker L, Rytkönen S, Vatka E, et al: Different seasonal patterns in song system volume in willow tits and great tits. Brain Behav Evol 2016;87:265-274.

Smith GT, Brenowitz EA, Wingfield JC: Seasonal changes in the size of the avian song control nucleus HVC defined by multiple histological markers. J Comp Neurol 1997;381:253-261.

Thompson CK, Brenowitz EA: Seasonal change in neuron size and spacing but not neuronal recruitment in a basal ganglia nucleus in the avian song control system. J Comp Neurol 2005;481:276-283.

Tramontin AD, Brenowitz EA: Seasonal plasticity in the adult brain. Trends Neurosci 2000;23:251-258. 